\title{
LEVERAGE, PROFITABILITAS, DAN KEPEMILIKAN MANAJERIAL BERPENGARUH TERHADAP NILAI PERUSAHAAN PADA PERUSAHAAN REAL ESTATE DAN PROPERTY
}

\author{
Luh Putu Putri Adesia Widayanti ${ }^{1}$ \\ I Putu Yadnya ${ }^{2}$ \\ ${ }^{1,2}$ Fakultas Ekonomi dan Bisnis Universitas Udayana (Unud), Bali, \\ Indonesia \\ email: adesyaw@gmail.com
}

\begin{abstract}
ABSTRAK
Nilai Perusahaan merupakan tujuan utama yang harus dicapai perusahaan karena dengan memaksimalkan nilai perusahaan berarti memaksimalkan kemakmuran pemegang saham. Investor akan mencari perusahaan yang mempunyai prospek perusahaan yang bagus sehingga menghasilkan tingkat return perusaham yang tinggi. Hal ini tentunya akan mempengaruhi tinggi rendahnya harga pasar saham suatu perusahaan, yang mencerminkan nilai perusahaan. Tujuan penelitian ini untuk mengetahui pengaruh leverage, profitabilitas, dan kepemilikan manajerial terhadap nilai perusahaan. Penelitian dilakukan pada perusahaan Real Estate dan property yang terdapat di Bursa Efek Indonesia tahun 20142018. Sampel yang digunakan yaitu 15 perusahaan, dengan purposive sampling. Pengumpulan data dilakukan dengan metode observasi non partisipan melalui data laporan keuangan yang dipublikaskan di Bursa Efek Indonesia. Teknik analisis yang digunakan yaitu analisis regresi linear berganda. Dalam penelitian ini ditemukan bahwa leverage, profitabilitas dan kepemilikan manajerial berpengaruh positif terhadap nilai perusahaan. Perusahaan diharapkan dapat memperhatikan rasio leverage, profitabilitas, dan kepemilikan manajerial agar nilai perusahaan semakin meningkat.
\end{abstract}

Kata kunci : Leverage, Profitabilitas, Kepemilikan Manajerial, Nilai Perusahaan

\begin{abstract}
Company Value is the main goal that must be achieved by the company. Investors will look for companies that have good prospects to get high level of company return. This will certainly affect the prices of a company's stock market, which reflects the value of the company. The purpose of this study was to determine the effect of leverage, profitability, and managerial ownership on firm value. The study was conducted on Real Estate and property companies on the Indonesia Stock Exchange 2014-2018. The samples used were 15 companies, with purposive sampling. Data collected using non-participant observation through financial statement on the Indonesia Stock Exchange. Multiple linear regression was used. In this study it was found that leverage, profitability and managerial ownership had positive effect on firm value. The company is expected to pay attention to the leverage ratio, profitability, and managerial ownership so that the company's value increases.

Keywords: Leverage, Profitability, Managerial Ownership, Company Value
\end{abstract}




\section{PENDAHULUAN}

Tujuan utama perusahaan yaitu memperoleh laba, memaksimalkan laba atau kekayaan, dan memaksimalkan nilai perusahaan. Peningkatan nilai perusahaan yang tinggi merupakan tujuan jangka panjang yang seharusnya dicapai perusahaan. Nilai perusahaan merupakan persepsi investor terhadap perusahaan yang sering dikaitkan dengan harga saham. Nilai perusahaan yang tinggi menjadi keingininan pemegang saham dan pemilik perusahaan karena mengindikasikan tingginya kemakmuran pemegang saham (Rahmawati et al., 2015)

Nilai perusahaan pada dasarnya dapat diukur melalui beberapa aspek, salah satunya adalah harga pasar saham perusahaan. Harga pasar merupakan harga saham perusahaan yang terbentuk antara pembeli dan penjual disaat terjadi transaksi atau biasa disebut nilai pasar perusahaan, karena harga pasar saham dianggap cerminan dari nilai aset perusahaan sesungguhnya. Memaksimalkan nilai pasar perusahaan sama dengan memaksimalkan harga pasar saham. Harga pasar saham merupakan salah satu indikator yang digunakan untuk mengukur nilai perusahaan yang diamati melalui pergerakan harga saham pada perusahaan yang sudah go public (Puspitaningtyas, 2017).

Harga saham yang meningkat, akan berdampak pada peningkatan nilai pemegang saham yang dibuktikan melalui tingginya gain bagi pemegang saham. Peningkatan nilai perusshaan yang tercermin dari tingginya harga saham akan membuat pasar percaya terhadap kinerja dan prospek perusahaan dalam mengelola dana investasinya, sehingga return yang diterima oleh pemegang saham akan optimal. Memaksimalkan nilai perusahaan dan meningkatkan laba merupakan tujuan perusahaan yang saling berkaitan untuk meningkatkan kesejahteraan para pemegang saham, sehingga tujuan tersebut akan menjadi kriteria yang penting untuk menjaga kelangsungan hidup perusahaan (Rudangga \& Sudiarta, 2016)

Nilai perusahaan yang dicerminkan melalui harga saham biasanya ditentukan oleh dua faktor utama, yaitu faktor fundamental dan teknikal. Biasanya faktor fundamental yang sering digunakan sebagai dasar pengambilan keputusan oleh para investor untuk menanamkan sahamnya pada perusahaan (Endhiarto, 2018). Faktor fundamental ini digunakan untuk menganalisis nilai suatu perusahaan dengan mengolah data yang bersumber dari laporan keuangan perusahaan (Štangová, 2016).

Faktor fundamental sangat kompleks dan luas cakupannya, meliputi faktor fundamental makro yang berada di luar kendali perusahaan, terdiri dari inflasi, tingkat suku bunga, kurs, pertumbuhan ekonomi dan faktor fundamental mikro yang berada di dalam kendali perusahaan meliputi rasio keuangan. Sedangkan faktor teknikal lebih bersifat teknis dengan melihat data historis harga saham terdiri dari volume perdagangan saham, nilai transaksi perdagangan saham, dan kecenderungan naik turunnya harga saham yang biasanya juga dilakukan oleh investor dalam menganalisis saham (Rakhimsyah \& Gunawan, 2014) 
Industri real estate dan property menjadi salah satu bahan pertimbangan investor untuk berinvestasi. Industri ini diprediksi mengalami pertumbuhan sebagai akibat dari pembangunan infrastruktur yang dilakukan pemerintah selama lima tahun belakangan ini. Namun, nyatanya pembangunan infrastruktur belum mampu untuk membuat sektor ini tumbuh terbukti pada beberapa tahun belakangan ini sektor real estate dan property masih lesu karena kondisi perekonomian Indonesia diketahui mengalami perlambatan sejalan dengan daya beli masyarakat yang menurun beberapa tahun terakhir. Daya beli masyarakat yang lemah tidak mampu membeli tingginya harga properti yang menyebabkan investasi pada beberapa tahun terakhir menurun, yang menyebabkan perusahaan pengembang sulit menjual aset propertinya. Hal ini sejalan dengan harga indeks saham sektoral Real Esate dan Property yang mengalami fluktuasi tahun 2014 hingga 2018. Gambar 1. menyajikan indeks harga saham perusahaan real esate dan property tahun 2014 hingga 2018 sebagai berikut:

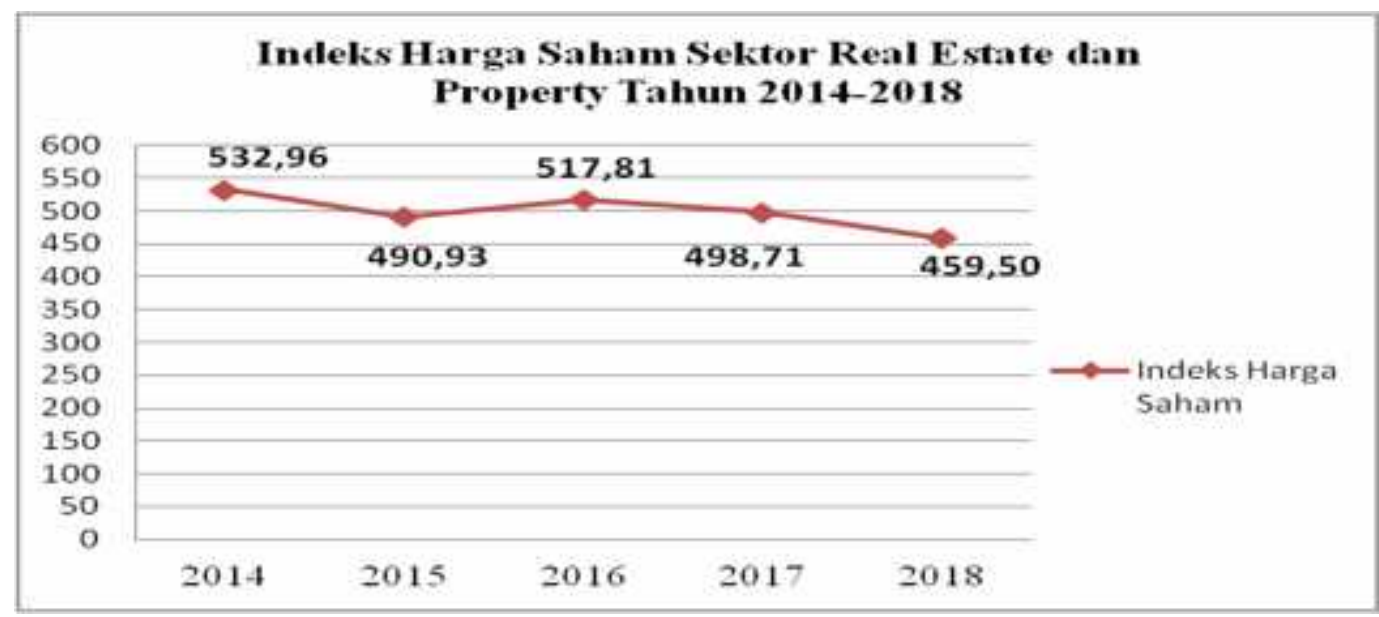

Gambar 1. Grafik Indeks Harga Saham Perusahaan Real Esate dan Property Tahun $2014-2018$

Sumber: Data Diolah, 2019

Gambar 1. menunjukan bahwa indeks harga saham perusahaan Real Esate dan Property, pada tahun 2014 hingga 2018 mengalami fluktuasi. Penurunan pertumbuhan indeks harga saham perusahaan Real Esate dan Property pada tahun 2015 sebesar 490,93 disebabkan oleh kenaikan suku bunga, pemberlakuan rasio kredit terhadap nilai aset pinjaman, depresiasi rupiah dan tingkat inflasi. Puncaknya pada tahun 2018 harga saham mengalami penurunan sebesar 459,50 yang disebabkan oleh peningkatan harga properti yang masih tinggi, ketidakpastian politik menjelang pemilu mendatang, dan adanya pengawasan dari otoritas pajak sehingga masyarakat lebih memilih menyimpan modalnya pada bank daripada berinvestasi di sektor real estate dan property

Selain itu, fenomena lain yang menunjukkan menurunnya nilai perusahaan dapat dilihat dengan menurunnya nilai rasio PBV (Price Book 
Value) pada sektor real estate dan property tahun 2014 hingga 2018. Nilai perusahaan tidak hanya dapat digambarkan pada harga saham suatu perusahaan saja, tetapi dapat dilakukan dengan berbagai cara, dan salah satu alat ukur yang dapat digunakan yaitu Price to Book Value (PBV). PBV merupakan rasio keuangan yang membandingkan antara harga saham dengan nilai buku per lembar saham Dibawah ini disajikan grafik rata - rata nilai PBV perusahaan real estate dan property yang mengalami penurunan tahun 2014 hingga 2018 sebagai berikut

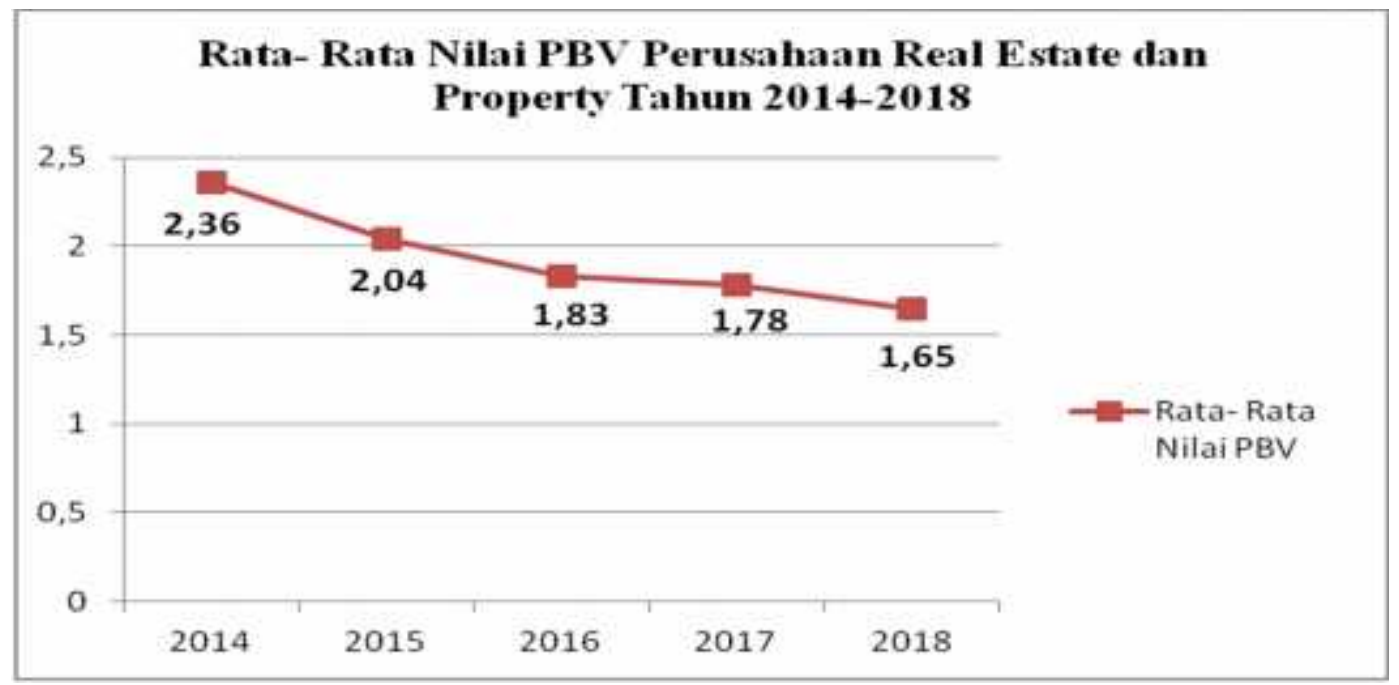

Gambar 2 . Rata-rata Nilai PBV Perusahaan Real Esate dan Property Tahun $2014-2018$

Sumber: Data Diolah, 2019

Berdasarkan Gambar 2. menyajikan indeks pertumbuhan rata-rata nilai perusahaan yang diukur dengan rasio PBV setiap tahunnya. Grafik tersebut menunjukan bahwa pada periode 2014 hingga 2018 perusahaan Real Esate dan Property mengalami penurunan nilai yang signifikan setiap tahunnya. Pada tahun 2014 perusahaan memiliki pertumbuhan nilai PBV sebesar 2,36 kemudian pada tahun 2015 mengalami penurunan sebesar 2,04 penurunan ini berlanjut hingga tahun 2018 sebesar 1,65. Semakin tinggi rasio PBV menunjukkan bahwa pasar semakin yakin akan prospek perusahaan tersebut. Dengan menurunnya nilai PBV menunjukkan bahwa pasar belum yakin terhadap prospek perusahaan yang tentunya akan berdampak pada menurunnya nilai perusahaan.

Fenomena tersebut menunjukan bahwa sektor real esate dan property mengalami penurunan rata-rata PBV menggambarkan menurunnya nilai perusahaan. Dengan menurunnya nilai perusahaan dapat dilihat kinerja perusahaan berdasarkan laporan keuangan perusahaan sehingga dapat ditentukan faktor yang dapat mempengaruhi nilai perusahaan. Faktor-faktor yang mempengaruhi nilai perusahaan dapat dibedakan menjadi faktor internal dan eksternal. 
Faktor internal yaitu faktor yang mempengaruhi nilai perusahaan dari dalam perusahaan itu sendiri dengan menganalisis kinerja keuangan yang meliputi: kepemilikan manajerial, kepemilikan institusional, kebijakan ividen, leverage, ukuran perusahaan, profitabilitas serta good corporate governance. Sedangkan faktor eksternal yaitu faktor yang mempengaruhi nilai perusahaan dari luar perusahaan seperti tingkat suku bunga, imflasi dan nilai kurs. Dalam penelitian ini dipilih beberapa faktor internal yang digunakan sebagai variabel karena sifatnya berada didalam perusahaan itu sendiri sehingga lebih efektif dan mudah dikendalikan oleh perusahaan (controllable). Diantara faktor internal yang dapat mempengaruhi nilai perusahaan tersebut yang dipilih sebagai variabel dalam penelitian ini yaitu leverage, profitabilitas dan kepemilikan manajerial.

Perusahaan memiliki sumber pendanaan yang berasal dari dalam (intern) maupun luar (ekstern) perusahaan. Pemenuhan kebutuhan dana yang berasal dari dalam perusahaan bersumber dari laba ditahan dan penyusutan. Jika pendanaan perusahaan yang bersumber dari dalam perusaahaan masih mengalami kekurangan maka, perlu dipertimbangkan pendanaan yang berasal dari luar perusahaan yaitu dari utang. Rasio yang mengukur seberapa besar perusahaan menggunakan pendanaan yang berasal dari utang disebut leverage.

Pengelolaan leverage sangatlah penting, sebab keputusan dalam penggunaan utang yang tinggi dapat meningkatkan nilai perusahaan dikarenakan adanya pengurangan atas pajak penghasilan. Hal ini terjadi karena utang yang dimiliki oleh perusahaan merupakan beban tetap, yaitu berupa beban bunga. Semakin tinggi utang yang dimiliki oleh perusahaan, maka beban bunga yang harus dibayarkan juga relatif semakin tinggi. Perusahaan yang cenderung memiliki utang yang tinggi akan mendapatkan insentif pajak berupa potongan atas bunga pinjaman, oleh sebab itu perusahaan yang memiliki beban pajak yang tinggi melakukan penghematan pajak dengan cara perusahaan tersebut menambahkan utang perusahaan yang dimilikinya

Hasil penelitian terdahulu yang dilakukan oleh Pratama \& Wiksuana (2016), Mukherjee \& Sen (2018) serta Farooq \& Masood (2015) menyatakan bahwa leverage berpengaruh positif terhadap nilai perusahaan. Penelitian lain yang dilakukan Aggarwal \& Zhao (2017) dan Ramadan (2015) menyatakan leverage berpengaruh negatif terhadap nilai perusahaan. Namun, terdapat hasil berbeda dari penelitian Sambora et al. (2014) yang menemukanbahwa leverage tidak berpengaruh terhadap nilai perusahaan.

Suatu perusahaan haruslah berada dalam keadaan yang menguntungkan (profitable), karena tanpa adanya keuntungan akan sulit bagi perusahaan untuk menarik modal dari luar perusahaan atau investor (Zuhroh, 2019). Perusahaan yang memiliki tingkat profitabilitas yang tinggi akan diminati sahamnya oleh investor, sehingga profitabilitas dapat mempengaruhi nilai perusahaan. Profitabilitas memiliki pengaruh yang positif terhadap nilai perusahaan. Profit yang tinggi akan memberikan indikasi prospek perusahaan yang baik sehingga dapat memicu investor untuk ikut meningkatkan 
permintaan saham. Permintaan saham yang meningkat tentunya akan menyebabkan nilai perusahaan yang meningkat pula (Husna \& Satria, 2019)

Profitabilitas merupakan salah satu faktor yang secara teoritis menentukan nilai suatu perusahaan. Perusahaan yang mampu menghasilkan laba yang tinggi dan stabil akan menarik para investor untuk menanamkan sahamnya pada perusahaan, karena secara langsung akan menguntungkan bagi investor. Kemampuan perusahaan yang besar untuk menghasilkan laba juga menunjukkan manajemen perusahaan yang baik, sehingga menumbuhkan kepercayaan pada investor. Kepercayaan investor ini pada akhirnya dapat menjadi instrumen yang paling efektif untuk meningkatkan harga saham perusahaan. Peningkatan harga saham sama artinya meningkatkan nilai perusahaan, sehingga lebih lanjut dapat menjamin kemakmuran pemegang saham (Lubis et al., 2017)

Hasil ini sesuai dengan penelitian yang dilakukan oleh Tui et al. (2017), Rasyid et al. (2015), serta Lestari \& Mursalim (2016) yang menyatakan bahwa profitabilitas berpengaruh positif terhadap nilai perusahaan. Hasil yang berlawanan diperoleh dari penelitian Herawati (2014) yang menyatakan profitabilitas berpengaruh negatif terhadap nilai perusahaan.

Faktor lain yang dapat mempengaruhi nilai perusahaan adalah Kepemilikan Manajerial. Kepemilikan manajerial adalah besarnya kepemilikan saham yang dimiliki oleh para manajer pada perusahaan. Optimalisasi nilai perusahan dapat dicapai melalui pelaksanaan fungsi manajemen keuangan, salah satu keputusan keuangan yang diambil akan mempengaruhi keputusan keuangan lainnya dan berdampak pada nilai perusahaan (Wijaya et al., 2017).

Pada dasarnya tujuan manajemen keuangan adalah memaksimalkan nilai perusahaan, akan tetapi terdapat konflik antara pemegang saham dengan para manajer. Hal ini terjadi ketika pemegang saham mempercayakan pengelolaan perusahaannya kepada para manajer. Perbedaan kepentingan antara para manajer dan pemegang saham ini menimbulkan konflik yang biasa disebut agency conflict. Konflik ini disebabkan oleh para manajer cenderung mengutamakan kepentingan pribadi yang tidak sesuai dengan tujuan yang ingin dicapai oleh para pemegang saham yaitu memaksimalkan kesejahteraan pemilik. Pemegang saham atau pemilik perusahaan akan berusaha mengatasi konflik ini dengan melakukan pengawasan terhadap para manajer, namun dalam mengatasi konflik tersebut akan menimbulkan biaya yang disebut dengan agency cost atau biaya keagenan.

Biaya yang ditanggung pemegang saham untuk mengawasi manajer dikenal dengan agency cost. Salah satu cara untuk memperkecil biaya agency cost adalah dengan memberikan kepemilikan saham perusahaan kepada para manajer. Kepemilikan saham yang diberikan kepada para manajer disebut kepemilikan manajerial. Dengan adanya kepemilikan manajerial, memberikan kesempatan bagi para manajer untuk ikut terlibat langsung dalam kepemilikan saham, sehingga secara langsung akan membuat kedudukan yang sejajar dengan para pemegang saham. Hal ini efektif bagi manajer untuk meningkatkan kinerja perusahaan dan meningkatkan laba perusahaan yang dapat meningkatkan nilai perusahaan (Sujoko \& Soebiataro, 2017) 
Penelitian terdahulu yang dilakukan oleh Muryati \& Suardikha (2014), Sholekah (2014), Basu et al. (2016) yang menyatakan kepemilikan manajerial berpengaruh positif terhadap nilai perusahaan. Hasil yang berlawanan juga didapat dari Rahma (2014) menyatakan kepemilikan manajerial berpengaruh negatif terhadap nilai perusahaan, namun penelitian lain dari Ambarwati \& Stephanus (2014), serta Georgeta (2015) menyatakan kepemilikan manajerial tidak berpengaruh signifikan terhadap nilai perusahaan

Berdasarkan fenomena dan research gap yang terdapat dalam latar belakang tersebut maka yang menjadi rumusan masalah dalam penelitian ini sebagai berikut: 1) Apakah terdapat pengaruh Leverage terhadap Nilai Perusahaan? 2) Apakah terdapat pengaruh Profitabilitas terhadap Nilai Perusahaan? 3) Apakah terdapat pengaruh Kepemilikan Manajerial terhadap Nilai Perusahaan?

Penelitian ini diharapkan dapat memperkaya bukti empiris sehingga menambah wawasan atau pengetahuan mengenai pengaruh Leverage, Profitabilitas, dan Kepemilikan manajerial terhadap Nilai Perusahaan pada Perusahaan Real Estate dan Property di Bursa Efek Indonesia. Secara praktis hasil penelitian ini diharapkan dapat digunakan sebagai bahan pertimbangan emiten untuk mengevaluasi, memperbaiki, dan meningkatkan kinerja manajemen dimasa yang akan datang mengenai Pengaruh Leverage, Profitabilitas, dan Kepemilikan Manajerial terhadap Nilai Perusahaan pada Perusahaan Real Estate dan Property di Bursa Efek Indonesia.

Teori yang digunakan adalah Teori keagenan (agency theory) dan Signaling theory adalah hubungan atau kontrak antara principal dan agent. Para manajer suatu perusahaan sebagai agent dan pemegang saham atau pemilik perusahaan sebagai principal. Pemegang saham yang merupakan principal mendelegasikan pengambilan keputusan bisnis kepada para manajer yang merupakan perwakilan atau agen dari pemegang saham.

Permasalahan yang muncul sebagai akibat sistem kepemilikan perusahaan seperti ini adalah agen tidak selalu membuat keputusan-keputusan yang bertujuan untuk memenuhi kepentingan terbaik bagi pemegang saham. Konflik ini terjadi karena para manajer sebagai pengelola (agent) memiliki informasi lebih mengenai perusahaan dibandingkan dengan pemilik (principal). Konflik dapat berkurang ketika pihak manajemen ikut andil dengan cara memiliki proporsi saham dalam perusahaan tersebut karena agent dan principal memiliki tujuan yang sama, sehingga manajemen dapat sepenuhnya memperhatikan dan fokus terhadap tujuan perusahaan yaitu meningkatkan nilai perusahaan.

Signaling theory menjelaskan bagaimana seharusnya sebuah perusahaan memberikan sinyal kepada pengguna laporan keuangan. Sinyal ini berupa informasi mengenai apa yang sudah dilakukan oleh menajemen untuk merealisasikan keinginan pemilik. Informasi tersebut selanjutnya dikeluarkan oleh perusahaan sebagai sinyal bagi para pelaku pasar atau investor untuk menanamkan modalnya pada perusahaan.

Leverage dalam Signalling theory menyatakan bahwa semakin tinggi tingkat utang perusahaan, maka memungkinkan perusahaan mampu untuk 
membayar utang dari keuntungan perusahaan yang diperolehnya karena perusahaan dianggap memiliki kondisi keuangan yang baik yang dapat menanggung resiko akibat tingginya utang tersebut. Tingginya utang perusahaan juga akan meningkatkan pertumbuhan investasi karena menambah sumber pendanaan yang dimiliki perusahaan. Besarnya dana yang dimiliki perusahaan, sebagian besar akan digunakan dalam kegiatan reinvestasi guna pencapaian laba yang lebih tinggi dimasa mendatang. Peningkatan utang dapat memberikan sinyal positif oleh investor sebagai meningkatnya kesempatan perusahaan untuk berkembang. Hal ini akan meningkatkan harga saham yang berarti meningkatkan nilai perusahaan.

Dengan laba yang tinggi akan membuat tingginya tingkat pengembalian modal (return) terhadap investor sehingga meningkatkan harga saham yang artinya meningkatkan nilai perusahaan. Perusahaan yang dapat mengelola leverage dengan baik biasanya dapat meningkatkan kepercayaan investor sehingga dapat meningkatkan nilai perusahaan. Hal ini didukung dengan teori Modigliani dan Miller mengemukakan bahwa penambahan utang akan menaikkan nilai perusahaan. Kenaikan utang hingga suatu batas optimal tertentu dipandang sebagai peningkatan kemampuan perusahaan dalam melunasi kewajibannya sehingga dipandang positif oleh pasar dan nilai perusahaan akan meningkat. Hasil ini didukung oleh penelitian yang dilakukan oleh Aggarwal \& Zhao (2017) dan Ramadan (2015) menyataka bahwa leverage berpengaruh positif terhadap nilai perusahaan.

$\mathrm{H}_{1}$ : Leverage berpengaruh positif terhadap nilai perusahaan

Secara teoritis meningkatnya profitabilitas perusahaan akan meningkatkan nilai perusahaan. Hal tersebut dikarenakan profitabilitas merupakan sinyal bagi investor agar tertarik untuk berinvestasi pada perusahaan. Tingginya profitabilitas perusahaan akan menarik bagi investor untuk menanamkan modalnya dengan melakukan permintaan pembelian saham perusahaan karena investor akan mneilai perusahaan memiliki kinerja yang baik sehingga mampu menghasilkan pengembalian investasi (return) yang tinggi juga bagi investor. Dengan demikian, harga saham pun akan meningkat karena tingginya permintaan saham yang mengindikasikan meningkatnya nilai perusahaan. Hasil penelitian ini didukung oleh penelitian yang dilakukan oleh Tui et al. (2017), Rasyid et al. (2015), serta Lestari \& Mursalim (2016) yang menunjukkan bahwa profitabilitas berpengaruh positif terhadap nilai peusahaan.

$\mathrm{H}_{2}$ : Profitabilitas berpengaruh positif terhadap nilai perusahaan

Konflik antara para manajer dan pemegang saham atau yang sering disebut dengan masalah keagenan dapat diminimumkan dengan suatu mekanisme pengawasan yang dapat mensejajarkan kepentingan-kepentingan sehingga dapat mengurangi biaya keagenan atau agency cost. Secara teoritis, dengan adanya kepemilikan manajerial ini dapat mengurangi konflik keagenan sehingga dapat meningkatkan nilai perusahaan karena antara pihak manajemen dengan pemilik atau pemegang saham memiliki tujuan yang sama. Hal ini sejalan dengan adanya penelitian yang dilakukan oleh Muryati \& 
Suardikha (2014), Sholekah (2014), Basu et al. (2016) yang menunjukkan kepemilikan manajerial berpengaruh positif terhadap nilai perusahaan.

$\mathrm{H}_{3}$ : Kepemilikan manajerial berpengaruh positif terhadap nilai perusahaan

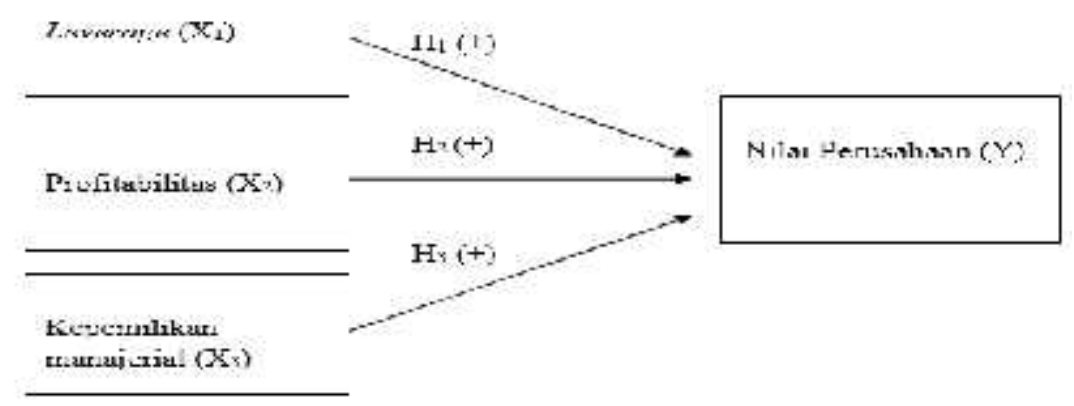

\section{Gambar 3. Kerangka Konseptual}

\section{METODE PENELITIAN}

Penelitian ini tergolong sebagai penelitian asosiatif. Dalam penelitian ini variabel terikat adalah Nilai Perusahaan, sedangkan variabel bebas adalah Leverage, Profitabilitas, dan Kepemilikan Manajerial. Lokasi pada penelitian ini terletak pada perusahaan real estate dan property yang terdaftar di Bursa Efek Indonesia tahun 2014-2018. Obyek pada penelitian ini adalah Nilai Perusahaan pada perusahaan real estate dan property pada tahun 2014-2018. Variabel terikat dalam penelitian ini adalah Nilai Perusahaan.Variabel bebas yang digunakan dalam penelitian ini yaitu: Leverage $\left(\mathrm{X}_{1}\right)$, Profitabilitas $\left(\mathrm{X}_{2}\right)$, Kepemilikan Manajerial $\left(\mathrm{X}_{3}\right)$

Nilai perusahaan merupakan persepsi investor terhadap keberhasilan perusahaan secara keseluruhan yang dilihat melalui harga saham. Dalam penelitian ini nilai perusahaan diukur menggunakan rasio PBV (Price Book Value), yaitu rasio perbandingan anatara nilai kinerja pasar saham dengan nilai bukunya pada perusahaan real estate dan property periode 2014 - 2018. PBV dapat dirumuskan sebagai berikut :

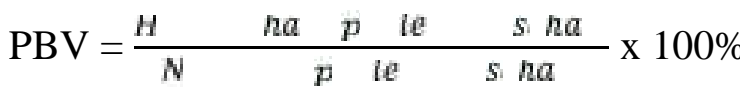

Leverage merupakan suatu rasio yang digunakan untuk mengetahui seberapa besar kemaampuan perusahaan dalam membayar seluruh kewajibannya. Dalam penelitian ini alat ukur yang digunakan untuk menghitung leverage yaitu debt to equity rasio (DER), yaitu presentase antara total utang dengan total ekuitas atau modal pada perusahaan real estate dan property tahun 2014 - 2018. Leverage dapat diukur dengan rumus sebagai berikut:

$\mathrm{DER}=\frac{T}{T} \times 100 \%$

Profitabilitas merupakan rasio yang digunakan untuk menilai kemampuan perusahaan dalam mencari keuntungan atau laba dalam satu periode tertentu. Pada 
penelitian ini diukur dengan ROE (Return On Equity) yaitu rasio profitabilitas yang menunjukkan presentase antara laba bersih dengan ekuitas/modal perusahaan real estate dan property pada tahun 2014- 2018. ROE dapat dirumuskan sebagai berikut:

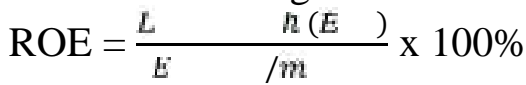

Kepemilikan manajerial merupakan persentase saham yang dimiliki oleh para manajer, direksi atau dewan komisaris. Dalam penelitian ini diproyeksikan dengan MOWN (Managerial Ownership) diukur dengan menggunakan skala rasio melalui presentase jumlah saham yang dimiliki pihak manajemen dengan jumlah saham perusahaan yang beredar pada perusahaan real estate dan property periode 2014-2018 Kepemilikan Manajerial dapat dirumuskan sebagai berikut:

$\operatorname{MOWN}=\frac{h \quad n s: n a 7}{h \quad n s i n a} \times 100 \%$

Populasi dalam penelitian ini adalah seluruh perusahaan real estate dan property yang terdaftar di BEI tahun 2014-2018. Jumlah populasi sebanyak 48 perusahaan. Metode penentuan sampel dalam penelitian ini dilakukan dengan menggunakan purposive sampling yaitu teknik penentuan sampel dengan kriteria tertentu. Adapun kriteria sampel dalam penelitian ini adalah sebagai berikut: 1) Perusahaan real estate dan property yang terdaftar di Bursa Efek Indonesia selama 5 (lima) tahun yaitu tahun 2014-2018. 2) Perusahaan real estate dan property yang memiliki laba selama 5 (lima) tahun yaitu tahun 2014-2018. 3) Perusahaan real estate dan property yang membagikan kepemilikan saham manajemen selama 5 (lima) tahun yaitu tahun 2014-2018.

Sampel yang diambil dalam penelitian ini adalah laporan keuangan tahunan yang diambil dari Perusahaan real estate dan property selama 4 (empat) tahun yaitu 2014 hingga 2018 yang terdaftar di Bursa Efek Indonesia (BEI). Terdapat sebanyak 15 perusahaan yang termasuk sampel penelitian yang sesuai dengan kriteria pada penentuan sampel tersebut. Teknik pengumpulan data dalam penelitian ini dilakukan dengan observasi non partisipan yang dilakukan dengan mengamati dan menganalisis laporan keuangan tahunan perusahaan real estate dan property tahun 2014 hingga 2018 yang diakses melalui situs resmi Bursa Efek Indonesia (BEI).

Jenis data yang dipergunakan dalam penelitian ini adalah data kuantitatif, yaitu data yang dinyatakan dalam bentuk angka yang bersumber dari publikasi laporan keuangan tahunan perusahaan real estate dan property di Bursa Efek Indonesia periode 2014 - 2018. Sumber data yang digunakan dalam penelitian ini adalah data sekunder yang diperoleh melalui situs resmi BEI di http:/www.idx.co.id pada perusahaan real estate dan property selama periode 2014 hingga 2018. 


\section{HASIL DAN PEMBAHASAN}

Objek dalam penelitian ini adalah perusahaan real estate dan property yang terdaftar di Bursa Efek Indonesia pada tahun 2014 hingga 2018. Real estate merupakan properti yang terdiri dari tanah dan bangunan di atasnya, bersama dengan sumber daya alam, kepentingan yang dipegang di dalamnya, dan juga sebagai suatu aset nyata yang secara umum diketahui sebagai bangunan atau perumahan. Sedangkan properti merupakan kepentingan dan hak-hak yang menyangkut kepemilikan tanah, bangunan, dan perbaikan yang menyatu terhadapnya. Oleh karena itu, baik real estate maupun property merupakan dua hal yang saling berkaitan satu sama lain, sehingga dapat disimpulkan bahwa industri real estate dan property merupakan kepentingan dan hak-hak yang menyangkut kepemilikan tanah, bangunan, dan perbaikan yang menyatu terhadapnya. Bidang usaha dari sektor property dan real estate meliputi berbagai macam bentuk seperti, apartemen, mall, gedung perkantoran, hotel, maupun perumahan. Keuntungan yang diperoleh bermacam-macam, tergantung dengan tipe investasinya, bisa berupa arus kas yang stabil (recuring income), capital gain, imbal hasil suku bunga, dan dividen.

Industri property dan real estate merupakan salah satu industri yang menjanjikan untuk berkembang di Indonesia, karena potensi jumlah penduduk yang besar dengan rasio pemilikan rumah yang masih rendah. dariinvestor. Perkembangan sektor ini begitu pesat saat ini dan diperkirakan akan semakin berkembang di masa yang akan datang. Hal ini terbukti dengan semakin banyaknya sektor Real Estate dan Property yang memperluas landbank (aset berupa tanah) dan mengkspansi bisnisnya.

Statistik deskriptif memberikan gambaran informasi mengenai data yang dilihat dari nilai minimum, nilai maksimum, nilai rata-rata (mean) dan standar deviasi dari variabel yang digunakan dalam penelitian ini, yaitu nilai perusahaan (PBV), leverage (DER), profitabilitas (ROE), dan kepemilikan manajerial (MOWN). Hasil deskriptif dapat dilihat pada Tabel 1. berikut:

Tabel 1.

Analisis Statistik Deskriptif

\begin{tabular}{lccccc}
\hline & N & Minimum & Maximum & Mean & Std. Deviation \\
\hline DER & 75 & 0.07 & 1.97 & 0.7384 & 0.47947 \\
ROE & 75 & 0.004 & 32.29 & 10.9597 & 7.51047 \\
MOWN & 75 & 0.0001 & 32.830 & 2.22669 & 5.578961 \\
PBV & 75 & 0.15 & 8.07 & 1.6472 & 1.60897 \\
Valid N (listwise) & 75 & & & & \\
\hline
\end{tabular}

Sumber: Data Diolah, 2019

Nilai minimum variabel nilai perusahaan yang diproksikan dengan PBV dihasilkan oleh perusahaan Greenwood Sejahtera Tbk (GWSA) tahun 2015 sebesar 0,15 sedangkan nilai maksimum dihasilkan oleh perusahaan Metropolitan Kentjana Tbk (MKPI) tahun 2017 sebesar 8,07. Nilai rata-rata sebesar 1,6472 artinya rata-rata perusahaan real estate dan property memiliki nilai PBV sebesar 164,72 persen. Standar deviasi PBV sebesar 1,60897atau 160,90 persen artinya 
terjadi penyimpangan nilai PBV terhadap nilai rata-rata sebesar 1,6090 atau 160,90 persen.

Nilai minimum variabel Leverage yang diproksikan dengan DER dihasilkan oleh perusahaan Greenwood Sejahtera Tbk (GWSA) tahun 2016 sebesar 0,07 sedangkan nilai maksimum dihasilkan oleh perusahaan Agung Pomodoro Land Tbk (APLN) tahun 2014 sebesar 1,97. Nilai rata-rata sebesar 0,7384 artinya ratarata perusahaan real estate dan property memiliki leverage sebesar $73,84 \%$. Standar deviasi DER sebesar 0,47947 atau 47,95 persen artinya terjadi penyimpangan nilai DER terhadap nilai rata-rata sebesar 0,47947atau 47,947 persen

Nilai minimum variabel nilai perusahaan yang diproksikan dengan ROE dihasilkan oleh perusahaan Pikko Land Development Tbk (RODA) tahun 2018 sebesar 0,004 sedangkan nilai maksimum dihasilkan oleh perusahaan Metropolitan Kentjana Tbk (MKPI) tahun 2016 sebesar 32,29. Nilai rata-rata sebesar 10,9597artinya rata-rata perusahaan real estate dan property memiliki profitabilitas sebesar 1095,97 persen. Standar deviasi ROE sebesar 7,51047atau 751,047 persen artinya terjadi penyimpangan nilai ROE terhadap nilai rata-rata sebesar 7,51047 atau 751,047 persen.

Nilai minimum variabel kepemilikan manajerial yang diproksikan dengan MOWN dihasilkan oleh perusahaan Danayasa Arthatama Tbk (SCBD) sepanjang tahun 2014-2018 sebesar 0,0001 sedangkan nilai maksimum dihasilkan oleh perusahaan Pikko Land Development Tbk (RODA) tahun 2017 dan 2018 sebesar 32,830 . Nilai rata-rata sebesar 2,22669artinya rata-rata perusahaan real estate dan property memiliki kepemilikan saham manajemen sebesar 222,669 persen. Standar deviasi MOWN sebesar 5,578961atau 557,8961 persen artinya terjadi penyimpangan nilai MOWN terhadap nilai rata-rata sebesar 5,578961atau 557,8961persen.

Sebelum pengujian hipotesis dilakukan, terlebih dahulu dilakukan pengujian terhadap gejala penyimpangan klasik. Uji asumsi klasik ini dilakukan untuk mengetahui kelayakan suatu model penelitian agar model regresi tidak bias. Model regresi yang baik adalah model regresi yang tidak mengandung masalah di dalam asumsi klasik.

Uji normalitas dilakukan untuk menguji apakah dalam model regresi, variabel pengganggu atau residual memiliki distribusi normal. Uji ini dilakukan dengan menggunakan One Kolmogorov-Smirnov dengan melihat nilai Asymp. Sig. (2-tailed). Jika nilai Asymp. Sig. (2-tailed) lebih besar taraf signifikansi yang ditetapkan yaitu 5 persen $(>0,05)$, maka data telah berdistribusi normal.

Tabel 2.

Hasil Uji Normalitas

\begin{tabular}{lc}
\hline & Unstandardized Residual \\
\hline $\mathrm{N}$ & 75 \\
Kolmogorov-Smirnov Z & 0,802 \\
Asymp. Sig. (2-tailed) & 0,541 \\
\hline Sumber: Data Diolah, 2019
\end{tabular}


Berdasarkan hasil analisis yang disajikan pada Tabel 2. diperoleh hasil nilai signifikan sebesar 0,541 lebih besar dari 0,05 ( $\mathrm{sig}=0,541>0,05)$ yang artinya data dalam penelitian ini berdistribusi normal.

Uji multikolinearitas bertujuan menguji apakah pada model regresi ditemukan adanya korelasi antar variabel bebas. Uji multikolinearitas dilakukan dengan melihat nilai variance inflation factor (VIF). Model regresi yang baik seharusnya tidak ada multikolinear. jika nilai VIF <10, maka dapat disimpulkan data bebas dari gejala multikoliearitas.

Tabel 3.

Hasil Uji Multikolinearitas

\begin{tabular}{crc}
\hline Model & \multicolumn{2}{c}{ Colinearity Statistic } \\
\cline { 2 - 3 } & Tolerance & VIF \\
\hline Leverage (X1) & 0,974 & 1,027 \\
Profitabilitas (X2) & 0,945 & 1,058 \\
Kepemilikan Manajerial (X3) & 0,945 & 1,059 \\
\hline Sumber: Data Diolah, 2019
\end{tabular}

Berdasarkan hasil analisis yang disajikan Tabel 3. dapat dilihat bahwa koefisien tolerance semua variabel lebih besar dari 0,10 (tolerance $=0,974$; 0,$945 ; 0,945>0,10$ ) dan nilai VIF yang lebih kecil dari 10 (VIF = 1,027; 1,058; $1,059<10)$. Hasil ini dapat disimpulkan bahwa tidak terdapat gejala multikolinear dari model regresi yang dibuat sehingga pada model regresi ditemukan korelasi antar variabel bebas.

Uji heterokedastisitas untuk menguji apakah terjadi ketidaksamaan varians pada model regresi. Model regresi dianggap layak jika tidak terjadi heterokedastisitas. Untuk mengetahui gejala heteroskedastisitas salah satunya dengan melakukan Uji Glejser yaitu meregresi nilai absolut terhadap variabel independen. Apabila nilai signifikan di atas 0,05 ( $\mathrm{sig}>0,05)$ maka tidak terjadi heteroskedastisitas pada model regresi.

Tabel 4.

Hasil Uji Heteroskedastisitas

\begin{tabular}{ccc}
\hline Model & Sig. & Keterangan \\
\hline Leverage $\left(\mathrm{X}_{1}\right)$ & 0,838 & Lolos Uji \\
Profitabilitas $\left(\mathrm{X}_{2}\right)$ & 0,090 & Lolos Uji \\
Kepemilikan Manajerial $\left(\mathrm{X}_{3}\right)$ & 0,314 & Lolos Uji \\
\hline
\end{tabular}

Sumber: Data Diolah, 2019

Berdasarkan hasil analisis yang disajikan pada Tabel 4. menunjukkan nilai signifikansi dari ketiga variabel lebih dari 0,05 dengan nilai signifikansi leverage (DER) sebesar 0,838, profitabilitas (ROE) sebesar 0,090 dan kepemilikan manajerial (MOWN) sebesar 0,314 artinya model regresi bebas dari gejala heteroskedastisitas.

Uji autokorelasi bertujuan menguji apakah dalam model regresi linier ada korelasi antara kesalahan pengganggu pada periode $\mathrm{t}$ dengan kesalahan pengganggu pada periode $(\mathrm{t}-1)$ periode sebelumnya. Untuk menguji gejala 
autokorelasi dapat menggunakan uji Durbin-Watson (DW test). Apabila kriteria yang diperoleh berupa DW test $\mathrm{d}>\mathrm{dU}$ dan DW test $<4$, maka model yang diteliti dapat dikatakan bebas dari autokorelasi

Tabel 5.

Hasil Uji Autokorelasi

\begin{tabular}{|c|c|c|c|c|c|}
\hline Model & $\mathbf{R}$ & R Square & $\begin{array}{c}\text { Adjusted R } \\
\text { Square }\end{array}$ & $\begin{array}{l}\text { Std. Error of the } \\
\text { Estimate }\end{array}$ & Durbin-Watson \\
\hline 1 & $0.702^{\mathrm{a}}$ & 0.492 & 0.471 & 1.17062 & 2.198 \\
\hline
\end{tabular}

Sumber: Data Diolah, 2019

Dalam penelitian ini menggunakan jumlah data (n) sebanyak 75 dengan sampel variabel bebas ( $\mathrm{k}^{\prime}$ ) sebanyak 3, sehingga diperoleh nilai dL sebesar 1,54 dan nilai dU sebesar 1,71, maka nilai 4-d $\mathrm{d}_{\mathrm{U}}$ adalah 2,29 (4-1,71). Hasil analisis yang disajikan tabel 4.6, nilai DW sebesar 2,198 berada diantara nilai $\mathrm{d}_{U}$ dan nilai $\mathrm{d}_{\mathrm{U}}<\mathrm{DW}<4-\mathrm{d}_{\mathrm{U}}(1,71<2,198<2,29)$, maka disimpulkan model regresi yang digunakan tidak ada autokorelasi.

Analisis regresi linier berganda digunakan untuk mengetahui besarnya pengarruh variabel bebas yaitu leverage, profitabilitas, dan kepemilikan manajerial terhadap variabel terikat yaitu nilai perusahaan pada perusahaan Real Estatae dan Property. Berdasarkan hasil perhitungan analisis regresi linear berganda pada Tabel 6 . maka ditemukan hasil persamaan regresi berganda sebagai berikut:

$\mathrm{Y}=-0,154+0,128 \mathrm{X}_{1}+0,174 \mathrm{X}_{2}+0,298 \mathrm{X}_{3}+\mathrm{e}$

Tabel 6.

Hasil Uji Analisis Regresi Linear Berganda

\begin{tabular}{rlccccc}
\hline \multirow{2}{*}{ Model } & \multicolumn{2}{c}{ Unstandardized Coefficients } & $\begin{array}{c}\text { Standardized } \\
\text { Coefficients }\end{array}$ & & T & Sig. \\
\cline { 3 - 5 } & & B & Std. Error & Beta & & \\
\hline \multirow{3}{*}{1} & (Constant) & -0.154 & 3.301 & & -0.047 & 0.963 \\
& DER & 0.128 & 0.064 & 0.193 & 2.009 & 0.048 \\
& ROE & 0.174 & 0.080 & 0.267 & 2.180 & 0.032 \\
& MOWN & 0.298 & 0.120 & 0.297 & 2.473 & 0.016 \\
\hline
\end{tabular}

Sumber: Data Diolah, 2019

Koefisien Konstanta variabel nilai perusahaan yang diproksikan dengan Price Book Value (PBV) yaitu -0,154 dengan tanda negatif mengindikasikan konstanta berpengaruh negatif. Hal ini menunjukkan bahwa apabila leverage, profitabilitas, dan kepemilikan mnajaerial suatu perusahaan tidak menjadi perhatian penuh perusahaan atau dalam keadaan konstan (0), maka nilai perusahaan yang dihasilkan menurun.

Nilai koefisien regresi $\left(\beta_{1}\right)$ variabel leverage yang diproksikan dengan Debt to Equiy Ratio (DER) sebesar 0,128. Hal ini berarti apabila DER perusahaan meningkat sebesar 1 persen, maka niai perusahaan akan meningkat sebesar 12,8 persen dan sebaliknya. Nilai koefisien regresi $\left(\beta_{2}\right)$ variabel profitabilitas yang diproksikan dengan Return On Equity (ROE) sebesar 0,174. Hal ini berarti apabila ROE perusahaan meningkat sebesar 1 persen, maka niai 
perusahaan akan meningkat sebesar 17,4 persen dan sebaliknya. Nilai koefisien regresi $\left(\beta_{3}\right)$ variabel kepemilikan manajerial yang diproksikan dengan Managerial Ownership (MOWN) sebesar 0,298. Hal ini berarti apabila MOWN perusahaan meningkat sebesar 1 persen, maka niai perusahaan akan meningkat sebesar 29,8 persen dan sebaliknya.

Uji kelayakan model dilakukan dengan melakukan uji $\mathrm{F}$ dan koefisien determinasi. Uji $\mathrm{F}$ digunakan untuk mengetahui apakah variabel bebas yaitu leverage, profitabilitas, dan kepemilikan manajerial memiliki pengaruh secara simultan terhadap variable terikat yaitu nilai perusahaan.

Tabel 7.

Hasil Uji F

\begin{tabular}{llccccc}
\hline Model & & $\begin{array}{c}\text { Sum of } \\
\text { Squares }\end{array}$ & Df & Mean Square & F & Sig. \\
\hline \multirow{2}{*}{1} & Regression & 94.276 & 3 & 31.425 & 22.932 & $.000^{\mathrm{b}}$ \\
& Residual & 97.294 & 71 & 1.370 & & \\
\hline & Total & 191.570 & 74 & & & \\
\hline
\end{tabular}

Sumber: Data Diolah, 2019

Berdasarkan hasil uji $\mathrm{F}$ pada Tabel 7. diatas, model regresi memiliki nilai Fhitung sebesar 22,932 dengan nilai signifikansi 0,000 yang lebih kecil dari 0,05. Jumlah data (n) dalam penelitian ini adalah 75 dengan jumlah variabel sebanyak 4. Uji $F$ dilakukan dengan melihat derajat bebas $\left(\mathrm{v}_{1}=\mathrm{k}-1\right) ;\left(\mathrm{v}_{2}=\mathrm{n}-\mathrm{k}\right)$. Nilai Ftabelyang diperoleh dari derajat bebas 3;71 ( $\left.\mathrm{v}_{1}=4-1 ; \mathrm{v}_{2}=75-4\right)$ adalah 2,733. Dengan diperolehnya nilai $F_{\text {hitung }}$ lebih besar daripada nilai $F_{\text {tabel }}(22,932>2,733)$ dan nilai signifikansi lebih kecil daripada taraf nyata $(0,000<0,05)$, maka dapat disimpulkan variabel bebas yaitu leverage $\left(\mathrm{X}_{1}\right)$, profitabilitas $\left(\mathrm{X}_{2}\right)$, dan kepemilikan manajerial $\left(\mathrm{X}_{3}\right)$ berpengaruh signifikan secara simultan terhadap variabel terikat yaitu nilai perusahaan $(\mathrm{Y})$.

Tabel 8.

Hasil Uji Koefisien Determinasi

\begin{tabular}{ccccc}
\hline Model & R & R Square & Adjusted R Square & $\begin{array}{c}\text { Std. Error of the } \\
\text { Estimate }\end{array}$ \\
\hline 1 & $0.702^{\mathrm{a}}$ & 0.492 & 0.471 & 1.17062 \\
\hline
\end{tabular}

Sumber: Data Diolah, 2019

Uji koefisien determinasi digunakan untuk mengukur seberapa jauh variabel terikat mampu dijelaskan oleh variable bebas dalam model regresi. Berdasarkan hasil analisis spss yang disajikan pada Tabel 8. diperoleh besarnya nilai Adjusted $\mathrm{R}$ square adalah sebesar 0,471 yang artinya sebesar 47,1 persen variasi nilai perusahaan dipengaruhi oleh leverage, profitabilitas, dan kepemilikan manajerial, sedangkan sisanya sebesar 52,9 persen dipengaruhi oleh faktor lain yang tidak dimasukkan ke dalam model penelitian.

Pada tahap ini, dilakukan pengujian dimana hasil analisis akan dinyatakan berpengaruh signifikan atau tidak sebagai pembuktian atas hipotesis yang dinyatakan dalam penelitian ini. Uji t digunakan untuk mengetahui bagaimana 
pengaruh masing-masing variabel bebas yaitu leverage (DER), profitabilitas (ROE) dan kepemilikan manajerial (MOWN) secara parsial terhadap variabel terikat yaitu nilai perusahaan (PBV)

Berdasarkan hasil uji regresi linear berganda, diketahui bahwa variabel leverage memiliki nilai koefisien beta positif sebesar 0,128 dengan nilai signifikansi sebesar 0,048. Nilai koefisien beta lebih dari 0 dan nilai signifikansi kurang dari 0,05 mengindikasikan bahwa leverage berpengaruh positif terhadap nilai perusahaan. Dengan demikian, $\mathrm{H}_{1}$ diterima.

Berdasarkan hasil uji regresi linear berganda, diketahui bahwa variabel profitabilitas memiliki nilai koefisien beta positif sebesar 0,174 dengan nilai signifikansi sebesar 0,032. Nilai koefisien beta lebih dari 0 dan nilai signifikansi kurang 0,05 mengindikasikan bahwa profitabilitas berpengaruh positif terhadap nilai perusahaan. Dengan demikian, $\mathrm{H}_{2}$ diterima.

Tabel 9.

Hasil Uji T

\begin{tabular}{rlcccrr}
\hline \multirow{2}{*}{ Model } & \multicolumn{2}{c}{ Unstandardized Coefficients } & $\begin{array}{c}\text { Standardized } \\
\text { Coefficients }\end{array}$ & & T & Sig. \\
\cline { 3 - 5 } & & B & Std. Error & Beta & & \\
\hline \multirow{3}{*}{1} & (Constant) & -0.154 & 3.301 & & -0.047 & 0.963 \\
& DER & 0.128 & 0.064 & 0.193 & 2.009 & 0.048 \\
& ROE & 0.174 & 0.080 & 0.267 & 2.180 & 0.032 \\
& MOWN & 0.298 & 0.120 & 0.297 & 2.473 & 0.016 \\
\hline
\end{tabular}

Sumber: Data Diolah, 2019

Berdasarkan hasil uji regresi linear berganda, diketahui bahwa variabel kepemilikan manajerial memiliki nilai koefisien beta positif sebesar 0,298dengan nilai signifikansi sebesar 0,016. Nilai koefisien beta lebih dari 0 dan nilai signifikansi kurang dari 0,05 mengindikasikan bahwa kepemilikan manajerial berpengaruh positif terhadap nilai perusahaan. Dengan demikian, H3 diterima.

Dari hasil uji hipotesis secara simultan (Uji F) pada Tabel 9 maka dapat disimpulkan bahwa variabel independen (leverage, profitabilitas dan kepemilikan manajerial) dalam penelitian ini secara bersama-sama berpengaruh terhadap variabel dependen yaitu nilai perusahaan. Secara parsial (Uji T) juga diperoleh hasil yang menunjukkan bahwa variabel yang memiliki pengaruh terhadap nilai perusahaan adalah ketiga variabel yaitu leverage, profitabilitas dan kepemilikan manajerial.

Berdasarkan hasil penelitian menunjukkan bahwa pada penelitian ini mendukung hipotesis pertama yang menyatakan leverage berpengaruh positif terhadap nilai perusahaan pada perusahaan real estate dan property periode 20142018. Arah positif tersebut memiliki arti semakin tinggi leverage maka semakin tinggi pula nilai perusahaan yang diperoleh. Perusahaan yang dapat mengelola leverage dengan baik biasanya dapat meningkatkan kepercayaan investor sehingga dapat meningkatkan nilai perusahaan.

Kenaikan hutang hingga suatu batas optimal tertentu dipandang sebagai peningkatan kemampuan perusahaan dalam melunasi kewajibannya sehingga dipandang positif oleh pasar meningkatnya kesempatan perusahaan untuk 
berkembang dan menghasilkan tingkat pengembalian investasi (return) yang lebih tinggi. Hasil penelitian ini sejalan dengan penelitian sebelumnya yang dilakukan oleh Pratama \& Wiksuana (2016), Mukherjee \& Sen (2018) serta Farooq \& Masood (2015) yang menunjukkan leverage berpengaruh positif terhadap nilai perusahaan.

Berdasarkan hasil penelitian menunjukkan penelitian ini mendukung hipotesis kedua yang menyatakan profitabilitas berpengaruh positif terhadap nilai perusahaan pada perusahaan real estate dan property periode 2014-2018. Arah positif tersebut menunjukkan semakin tinggi profitabilitas maka semakin tinggi pula nilai perusahaan. Hal ini terjadi karena tiingginya profitabilitas akan menjadi sinyal positif yang menarik bagi investor untuk menanamkan modalnya dengan melakukan permintaan pembelian saham pada perusahaan. Dengan tingginya profitablitas investor akan mneilai perusahaan memiliki kinerja yang baik sehingga mampu menghasilkan tingkat pengembalian investasi (return) yang tinggi bagi investor. Hasil penelitian ini sejalan dengan penelitian yang dilakukan sebelumnya oleh Tui et al. (2017), Rasyid et al. (2015), serta Lestari \& Mursalim (2016) yang menunjukkan profitabilitas berpengaruh positif signifikan terhadap nilai peusahaan.

Berdasarkan hasil penelitian menunjukkan penelitian ini mendukung hipotesis ketiga yang menyatakan bahwa kepemilikan manajerial berpengaruh positif terhadap nilai perusahaan pada perusahaan real estate dan property periode 2014-2018. Arah positif tersebut menunjukkan semakin tinggi kepemilikan manajerial maka semakin tinggi pula nilai perusahaan. Secara teoritis, dengan adanya kepemilikan manajerial ini dapat mengurangi konflik keagenan sehingga dapat meningkatkan nilai perusahaan karena antara pihak manajemen dengan pemilik atau pemegang saham memiliki tujuan yang sama. Dengan adanya kepemilikan saham ini biasanya efektif bagi manajer untuk meningkatkan kinerja sehingga dapat meningkatkan laba dan tingkat pengembalian investor. Hasil ini sejalan dengan penelitian sebelumnya yang dilakukan oleh Muryati \& Suardikha (2014), Sholekah (2014), Basu et al. (2016) yang menunjukkan hubungan yang positif antara kepemilikan manajerial terhadap nilai perusahaan.

Hasil penelitian ini memberikan tambahan informasi mengenai bagaimana pengaruh Leverage, Profitabilitas, dan Kepemilikan Manajerial terhadap Nilai Perusahaan. Dari penelitian ini terdapat bukti empiris yang diperoleh menunjukkan bahwa Leverage, Profitabilitas, dan Kepemilikan Manajerial berpengaruh positif signfikan terhadap nilai perusahaan pada perusahaanreal estate dan property. Hal ini menunjukkan bahwa tinggi rendahnya leverage, profitabilitas dan kepemilikan manajerial mempengaruhi tingkat pembelian saham pada investor sehingga menaikkan harga saham yang menjadi reflikasi dari tinggi rendahnya nilai perusahaan. Hasil ini sesuai dengan teori sinyal menyatakan bahwa informasi internal perusahaan sangat penting bagi nvestor dalam mengambil keputusan investasi pada perusahaan.

Hasil penelitian ini dapat menjadi pertimbangan bagi perusahaan maupun investor. Bagi perusahaan hasil ini dapat digunakan untuk meningkatkan nilai perusahaan dengan menganalisis laporan keuangan salah satunya dengan menggunakan rasio leverage, profitabilitas, dan kepemilikan manajerial sehingga 
perusahaan dapat mempertimbangkan setiap pengambilan keputusan keuangan yang diambil karena akan mempengaruhi kelangsungan hidup perusahaan di masa mendatang. Hasil ini juga bermanfaat bagi investor sebagai pertimbangan dan wawasan mengenai nilai perusahaan serta faktor-faktor yang mempengaruhi baik internal maupun eksternal.

\section{SIMPULAN}

Berdasarkan hasil dan pembahasan yang telah diuraikan sebelumnya, maka dapat disimpulkan Leverage berpengaruh positif terhadap nilai perusahaan. Hal ini menunjukkan bahwa semakin tinggi nilai leverage maka nilai perusahaan semakin meningkat. Profitabilitas berpengaruh positif terhadap nilai perusahaan. Hal ini menunjukkan bahwa semakin tinggi nilai profitabilitas maka nilai perusahaan semakin meningkat. Kepemilikan manajerial berpengaruh positif terhadap nilai perusahaan. Hal ini menunjukkan bahwa semakin tinggi nilai kepemilikan manajerial maka nilai perusahaan semakin meningkat.

Bagi perusahaan real estate dan property diharapkan penelitian ini dapat digunkan sebagai bahan pertimbangan dalam mengambil keputusan serta membuat kebijakan dalam rangka meningkatkan nilai perusahaan dengan memerhatikan kinerja keuangan diantaranya leverage, profitabilitas dan kepemilikan manajerial. Hal yang dapat dilakukan perusahaan yaitu, meningkatkan profit dan kepemilikan saham kepada para manajer, namun perlu berhati hati dalam penggunaan leverage yang terlalu tinggi karena dapat meningkatkan risiko kebangkrutan pada perusahaan. Oleh karena itu, perusahaan diharapkan dapat dengan bijak mengelola leverage sehingga mampu meningkatkan nilai perusahaan.

Bagi investor penelitian ini diharapkan menjadi pertimbangan sebelum melakukan investasi untuk memperhatikan terlebih dahulu faktor-faktor yang dapat mempengaruhi nilai perusahaan dengan menganalisis kinerja keuangan, diantaranya leverage, profiitabilitas, dan kepemilikan manajerial sehingga investor dapat memilih perusahaan yang secara optimal memberikan capital gain dan terhindar dari risiko tertentu. Bagi peneliti selanjutnya disarankan dapat melakukan penelitian dengan menambah atau mengganti faktor lain yang dapat mempengaruhi nilai perusahaan seperti: kepemilikan institusional, ukuran perusahaan, kebijakan dividen dan faktor lainnya serta menambah periode waktu penelitian dan menambah jumlah sampel penelitian dengan menambah sektor lain sehingga dapat diperoleh hasil penelitian yang lebih beragam.

\section{REFERENSI}

Aggarwal, R., \& Zhao, X. (2017). The Leverage-Value Relationship Puzzle: An Industry Effects Resolution. Journal Of Economics And Business, 59(4), 286-297. https://doi.org/doi.Org/10.1016/J.Jeconbus.2006.07.001

Ambarwati, I. ., \& Stephanus, D. . (2014). Struktur Kepemilikan,Kebijakan Dividen, dan Leverage sebagai Determinan Atas Nilai Perusahaan. Jurnal Akuntansi Multiparadigma, 5(2), 170- 184. 
Analisa, Y. (2011). Pengaruh Ukuran Perusahaan, Leverage, Profitabilitas dan Kebijakan Dividen Terhadap Nilai Perusahaan. Semarang: Universitas Diponegoro. https://doi.org/10.1364/ECEOC.2012.Tu.1.A.5

Basu, N., Paeglis, I., \& Rahnamaei, M. (2016). Multiple Blockholders, Power, And Firm Value. Journal of Banking \& Finance, 6(6), 66-78.

Endhiarto, T. (2018). The application of fundamental and technical model in the investment decision making: Empirical study on the companies listed in Jakarta Islamic index. International Journal of Scientific and Technology Research, 7(1), 80-86.

Farooq, M. A., \& Masood, A. (2015). Impact of Financial Leverage on Firms ' Profitability: An Investigation from Cement Sector of Pakistan. Research Journal Of Finance And Accounting, 6(7), 75-81.

Georgeta, V. (2015). Does Ownership Structure Influence Firm Value? An Empirical Research Toward The Bucharest Stock Exchange Listed Companies. International Journal of Economics and Financial, 5(2), 501514.

Haruman, T. (2008). Pengaruh Struktur Kepemilikan Terhadap Keputusan Keuangan dan Nilai Perusahaan Survey Pada Perusahaan Manufaktur di PT. Bursa Efek Indonesia. Universitas Widyatama. https://doi.org/10.1378/chest.119.4.1185

Herawati, T. (2014). Pengaruh Kebijakan Dividen, Kebijakan Hutang dan Profitabilitas terhadap Nilai Perusahaan. Jurnal Manajemen, 2(2), 1-18.

Husna, A., \& Satria, I. (2019). Effects of Return on Asset, Debt to Asset Ratio , Current Ratio , Firm Size, and Dividend Payout Ratio on Firm Value. International Journal of Economics and Financial Issues, 9(5), 50-54.

Lestari, A. ., \& Mursalim, A. (2016). Profitability and Company Value: Empirical Study of Manufacture Companies in Indonesia Period 2009-2014. Information Management and Business Review, 8(3), 6-10.

Lubis, I. L., Sinaga, B. M., \& Sasongko, H. (2017). Pengaruh Profitabilitas, Sruktur Modal, Dan Likuiditas Terhadap Nilai Perusahaan. Jurnal Aplikasi Bisnis Dan Manajemen, 3(3), 458-465. https://doi.org/doi.org/10.17358/jabm.3.3.458

Mukherjee, T., \& Sen, S. S. (2018). Impact of Financial Leverage on the Value of Firm : Evidence from Some NSE Listed Companies. The BESC Journal of Commerce and Management, 4(1), 42-52.

Muryati, N. N. T. S., \& Suardikha, I. M. S. (2014). Pengaruh Corporate Governance pada Nilai Perusahaan. E-Jurnal Akuntansi Universitas Udayana, 9(2), 411-429.

Pratama, I. G. B. A., \& Wiksuana, I. G. B. (2016). Pengaruh Ukuran Perusahaan 
Dan Leverage Terhadap Nilai Perusahaan Dengan Profitabilitas sebagai variabel Mediasi. E-Jurnal Manajemen Unud, 5(2), 1338-1367.

Puspitaningtyas, Z. (2017). Is Financial Performance Reflected in Stock Prices? Advances in Economics, Business and Management Research, 40(1), 17-28. https://doi.org/10.2991/icame-17.2017.2

Rahma, A. (2014). Pengaruh Kepemilikan Manajerial, Kepemilikan Institusional, dan Ukuran Perusahaan terhadap Keputusan Pendanaan dan Nilai Perusahaan (Studi Kasus Pada Perusahaan Manufaktur yang Terdaftar di Bursa Efek Indonesia Priode 2009-2012). Jurnal Bisnis Strategi, 23(2), 45-69.

Rahmawati, A. D., Topowijono, \& Sulasmiyati, S. (2015). Pengaruh Ukuran Perusahaan, Profitabilitas, Struktur Modal, dan Keputusan Investasi Terhadap Nilai Perusahaan. Jurnal Administrasi Bisnis, 35(1), 154-164.

Rakhimsyah, \& Gunawan. (2014). Pengaruh Keputusan Investasi, Keputusan Pendanaan, Kebijakan Deviden dan Tingkat Suku Bunga Terhadap Nilai Perusahaan. Jurnal Investasi, 7(1), 31-45.

Ramadan, I. Z. (2015). Leverage and the Jordanian Firms' Value: Empirical Evidence. International Journal of Economics and Finance, 7(4), 1-7.

Rasyid, A., Mahfudnurnajamuddin, \& Muhammad, S. (2015). Effect of Ownership Structure, Company Size and Prifitability on Dividend Policy and Manufacturing Company's Value in Indonesia Stock Exchange. Australian Journal of Basic and Applied Sciences, 9(20), 618-624.

Rudangga, G. N. G., \& Sudiarta, G. M. (2016). Pengaruh Ukuran Perusahaan, Leverage, Dan Profitabilitas Terhadap Nilai Perusahaan. E-Jurnal Manajemen Unud, 5(7), 4394-4422.

Sambora, M. N., Handayani, S. R., \& Rahayu, S. M. (2014). Pengaruh Leverage Dan Profitbilitas Terhadap Nilai Perusahaan. Jurnal Administrasi Bisnis, 8(1), 1-10. https://doi.org/10.1017/CBO9781107415324.004

Sholekah, F. W. (2014). Pengaruh Kepemilikan Manajerial, Kepemilikan Institusional, Leverage, Firm Size dan Corporate Social Responsibility terhadap Nilai Perusahaan pada Perusahaan High Profile yang Terdaftar di Bursa Efek Indonesia Periode Tahun 2008-2012. Jurnal Ilmu Manajemen (JIM), 2(3), 795-801.

Štangová, N. (2016). Information Sources for Financial Analyse in the Organisation. Ecoforum, 5(2), 194-199.

Sujoko, \& Soebiataro, U. (2017). Shareholding Structure Influence Leverage Factor Internal And External Factors Against Value Company (Empirical Study On The Manufacturing And Non-Manufacturing Companies In Jakarta Stock Exchange). Journal of Accounting \& Management, 9(1), 41-48.

Tui, S., Nurnajamuddin, M., Sufri, M., \& Nirwana, A. (2017). Determinants of 
Profitability and Firm Value: Evidence from Indonesian Banks. IRAInternational Journal of Management \& Social Sciences, 7(1), 84-95. https://doi.org/10.21013/jmss.v7.n1.p10

Wijaya, G. E., Wahyuni, M. A., \& Yuniarta, G. A. (2017). Pengaruh Asimetri Informasi, Ukuran Perusahaan, dan Kepemilikan Manajerial terhadap Praktek Manajemen Laba pada Perusahaan Manufaktur di Bursa Efek Indonesia (BEI) Tahun 2013-2015. Journal Akuntansi Ganesha, 8(2), 1-12.

Zuhroh, I. (2019). The Effects of Liquidity, Firm Size, and Profitability on the Firm Value with Mediating Leverage. KnE Social Sciences, 3(13), 203. https://doi.org/10.18502/kss.v3i13.4206 